\title{
LUGANIAN CHARACTER TWENTY YEARS LATER: NECESSARY CORRECTION
}

\section{Yeremenko O. M., Kroytor A. V.}

\section{INTRODUCTION}

In the mid-nineties of the last century, one of the authors published an article "Lugansk: Mythologized Past and Possible Future", in which an attempt was made to characterize "Lugansk character as a certain socio-psychological and cultural-cultural and cultural integrity", based on the method of included observation and analysis of some features of the history of Lugansk. The changes that have taken place since these times in the socio-political, everyday and mental life of the region and caused by the events that became the epicenter of Donetsk and Lugansk, have made some adjustments as in the reality of twenty years ago as in the theoretical positions of the mentioned work. The dynamics of the historical events of the modern era are the next: over a 20-year period, changes equivalent to the much longer stages of previous historical eras can fit. At the same time, the question arises: if the essential features of a particular socio-cultural phenomenon are highlighted, will they not be constant in the flow of historical change?

The aforementioned question determines the purpose of this article: to rethink the peculiarities of "urban character", on the one hand, in the context of the problem of metaphysics of the city, on the other hand, in the context of a specific historical event that has been covered by a particular city (Lugansk).

The theoretical basis of this article, as well as the article written in 1997, will be the theory of archetypal events, outlined in the work "History as eventfulness" $"$. As a methodological basis for rethinking the provisions of the article written in 1997, the authors will allow themselves to take the method of included observation since one of the authors was partly a close observer and partly a participant of the events of 2014.

The idea of the theory of archetypical events in general is following. In the history of almost every nation, there are events that have an extremely strong influence on its mentality. They set a kind of "super-task" and "program"

${ }^{1}$ Erëmenko A. M., Sneghyrëv V. V. (1997) Lughansk: myfologhyzyrovannoe proshloe y vozmozhnoe budushhee [Lugansk: mythologized past and possible future] Drevnosty Podoncovjja, pp. 81-84.

${ }^{2}$ Erëmenko A. M. (2005) Ystoryja kak sobytyjnostj: Monoghrafyja: V 2-kh t. T. 2. [History as an Event: Monograph: In 2 volumes. Volume 2] - Lughansk: RYO LAVD, (in Ukrainian) 
the people on the efforts aimed at completing the super-task. These events can be as real as legendary, and even a real archetypical event is always mythologized to some extent (mythologization of the Trojan War in the ancient Greek epos and Greek culture as a whole).

Due to the specificity of archetypical and other important events, there is a domination of optimistic or pessimistic, major or minor motifs that determine the general tone of mentality and culture of a nation. Some events have the character of psychotraumas. (On an event as an injury, see P. Stompka's works) $)^{3,4}$

\section{Imperial and Ukrainian historiography on the establishment of the cities of Lugansk and Odessa}

Archetypical events, as well as mythological images of actors, have a long-term influence on the consciousness and the collective unconscious of social communities. It is interesting that some events are more or less adequately remembered, others in a distorted light, and others are forgotten. And it is impossible to assert that the most important events are remembered, but the least important ones are forgotten: sometimes it happens exactly the opposite.

In this aspect, the theory of archetypical events can be compared with some provisions of psychoanalysis. For example, Z. Freud emphasizes that mental trauma causes various phenomena of substitution and disguise, which do not destroy this trauma. In specific circumstances, those things, that the patient has tried to forget, come back.

Reflecting on the regularities of the collective psychology, P. Ricoeur shows that on the level of collective memory, manipulation and forgetting strategies acquire more impressive dimensions than on the level of the individual memory. Among the forms of such manipulation are memoriesscreens, uncomfortable actions, the selectivity of stories about the historical past, manifesting itself in silences, shifting of accents, refigurations of participants of the action, and other forms. In Ricoeur's opinion, fundamental events form a certain "redundancy of memory" in nations, which resonates with Freud's analysis of the attraction to repeat ${ }^{5}$.

In the context of the theory of archetypical events, the controversy around the date of Lugansk's foundation is representative. Traditionally, such date is considered November 14, 1795. On this day Catherine II signed a decree

${ }^{3}$ Shtompka P. (2001) Kuljturnaja travma v postkommunystycheskom obshhestve [Cultural trauma in a post-communist society] Socyologhycheskye yssledovanyja, no. 2, pp. $23-38$.

${ }^{4}$ Shtompka P. (2001) Socyaljnoe yzmenenye kak travma (statjja pervaja) [Social change as trauma (article one) SOCYS., no. 1, pp. 6-16.

${ }^{5}$ P. Ricoeur (2004) Pamjatj, ystoryja, zabvenye [Memory, history, forgetting]. Moskva: Yzdateljstvo ghumanytarnoj lyteratury. (in Russian) 
"On the establishment of a foundry at the Lugansk River in Donetsk County and on the establishment of a scrap of coal found in that country".

The "town-based" meaning of the decree of 14.11 .1795 is denied by the local historians, who are guided by the Ukrainian historical narrative. They note that the decree is not yet a city, and the factory itself is not yet a city. The Ukrainian narrative emphasizes that the plant was built near the village of Kamenny Brod, which was founded by the Zaporizhzhia Cossacks in the mid18 th century ${ }^{6}$.

It is interesting that there is a similar conflict between the Ukrainian and the Great-Power Russian narrative regarding the problem of founding Odessa. There is a well-known controversy in the historical scientific community about the "genuine" foundation of Odessa. Supporters of the Ukrainian historical narrative object to the traditional date of 2 September 1794, when, according to the decree of Catherine II of 27 May 1794, the construction of a military harbour began. By the way, the style of the Empress's decrees regarding the foundation of a military factory on the Lugan river and a military harbor on the Black Sea coast is very similar: "Respecting the privileged position of Khadjibei at the Black Sea and the associated advantages, we recognized the need to arrange a military harbor there with a merchant's quay". (Compare it with the above-mentioned decree of November 14, 1795).

A group of Ukrainian historians postpones the date of foundation of Odessa to 1415 and even in older times. In 1415, for the first time appeared a mention of the port of Kachibey (Khajibey, Kochubey, Kujabey, etc.), which belonged to the Grand Duchy of Lithuania and was later conquered by the Ottoman Empire. There are also attempts to further "ancient" the history of Odessa, indicating that in the XIII-XIV centuries on the territory of the city there was a Genoese shipyard called Ginestra ${ }^{7}$.

So, the controversy around the foundation of Odessa has not faded in recent years and is especially active on the eve of the "City Day" celebration. This discussion has become influenced by the media, involving politicians and actively using political discourse. As D. Yakovlev and O. Eremenko note, "Political discourse, unlike many other discourses, is the most massive. It is the political discourse that is most fully transmitted by modern media, while political actors actively use communication technologies, which make it possible to fight for power the most effectively. On the one hand, it may seem that political discourse dominates others or is an autonomous sphere at all; but on the other hand, it is in political discourse that borrowing from other

${ }^{6}$ Zakharchenko R. S. (2007) Kam'janyj brid [The stone ford] Encyklopedija istoriji Ukrajiny: u 10 tomakh Tom 4 [Encyclopedia of Ukrainian History: in 10 volumes. Volume 4.

${ }^{7}$ Ystoryja osnovanye Odessy [History foundation of Odessa] Aghenstvo "Tudoj - Sjudoj" Retrieved from: https://tudoy-sudoy.od.ua/istoriya-osnovanie-odessy/ (accessed 11 February 2020) 
discourses, appealing to the discourse of other social groups, and citing and interpreting them are the most visible ${ }^{8}$.

Certainly, for a long time historical science developed in line with the generally accepted imperial Russian historiography. It was characterized by interpreting the beginning of the history of all cities, villages and towns of the Northern Black Sea coast from the end of the XVIII century. Therefore, for example, the majority of settlements in the Odessa region are considered to have been founded between the end of the XVIII century and the beginning of the XIX century, in particular, it concerns the city of Odessa, that officially celebrates its foundation in 1794 .

In particular, the site of the city on the eve of the "City Day" announced: "September 2, 2019 Odessa will celebrate the 225th anniversary of the founding of the city. On the occasion of the memorable date by the order of Odessa Mayor, the plan of measures to celebrate the Day of Odessa has been approved"'.

Most historians, however, have been chronicling the city since the founding of the fortress of Kotsyubey. In particular, A. Bachinskaya notes: "In historical science, the first written mention of any settlement is considered to be the beginning of history. Based on this principle, the scientist Alexander Boldyrev convincingly proved that in the case of Odessa it is 1415 , when information about the port of Kachibey, or Khajibey, first appeared in written sources. In his fundamental work "The History of Poland" the $15^{\text {th }}$-century chronicler Jan Dlugosz paid attention to the "Port of Kochibey". Talking about the events of 1415 , he wrote in particular: "... at that time came to the Polish king Wladyslaw ambassadors of the patriarch and Greek emperor with a letter and tin bulls, they were honored, and the Turks tortured and oppressed them in every way; they need generous help with grain. Wladyslaw, the Polish king in holy compassion, documentary certifies help. He gives and generously presents requests for the amount of grain that they need to get in his royal port of Kochubeyes. $^{10}$

This date is not ignored by the authors of the textbook "Odessa is my hometown" A. Levchishen, A. Pospelov who notes that "For the first time

${ }^{8}$ Eremenko A., Yakovlev D. (2019). "My dialektiku uchili ne po Gegelyu". Filosofiya v zerkale politicheskoy propagandy: popytka antropologicheskogo podkhoda ["We studied dialectics not according to Hegel". The philosophy in the mirror of political propaganda: an attempt to the anthropological approach] Current problems of philosophy and sociology, no. 24, pp. 10-23. https://doi.org/10.32837/apfs.v0i24.885 (accessed 11 February 2020)

${ }^{9}$ Denj ghoroda. Proghramma [City day. Program] Oficijnyj sajt mista Odesa Retrieved from: https://omr.gov.ua/ua/announce/216868/(accessed 11 February 2020)

${ }^{10}$ Bachynsjka O. Ghoncharuk T. (2014) ODESA ta ODJeSA - "ne dve boljshye raznycy" [ODESA and ODESA - "not two big differences"] Tyzhdenj ua [Week ua]. (electronic journal) Retrieved from: https://tyzhden.ua/Society/120970 (accessed 11 February 2020) 
Kochubey mentioned in the chronicle "History of Poland" in 1415 (here the author of "History" Ian Dlugosz was wrong for 7 years; in fact, the events he described took place in 1422). Dlugosz writes that there was a "port" in Kochubey, which belonged to Lithuanian prince Vitovt and Polish king Jagailo. From here, the rulers of the Polish-Lithuanian Duchy send on merchant ships a batch of grain to Constantinople, which was besieged by the Turks. But by the second half of the XV century, the power of the Duchy of Lithuania in these lands is weakening, and the shores of the current Gulf of Odessa again come to desolation. Remains of the Lithuanian castle of Kochubeyes, the travelers, passing by, saw only in the ruins. Thus, in 1578 Martin Bronevsky writes about its ruins "Kachibey castle fortress was like a landslide that is washed by a wide lake, and is located by the sea". Turkish traveler Evliya Celebi in 1657 reports: "If the fortifications are restored at least a little, the area will become inhabited again, and the road will became safe" $"$.

In this manual it was also noted that "in July 1709, on the ruins of Kochubey, near "a tiny Tatar village", the Swedish King Charles XII and the Ukrainian hetman Mazepa spent the night, heading after the defeat at Poltava under the protection of the Turkish fortress of Bender ... Only in $1765 \ldots$ on the eve of another war with Russia, the Turks began to repair the old medieval castle. However, the restored fortress, named Yeni-Dunya, looked miserable in comparison with such Turkish strongholds of the Black Sea region as Ochakov, Bendery or Izmail. Ukrainian Cossacks called the new castle a "krepostca". ${ }^{12}$

However, in contrast to the mentioned authors, which slightly reduces, perhaps deliberately, the importance of settlement around the fortress and the fortress itself. A. Bachinskaya and T. Goncharuk indicate that around the fortress developed a number of Cossack settlements, in particular, the researchers note: "In the second half of the XV century Kachibey, as well as the entire surrounding Black Sea coast were captured by the powerful Ottoman Empire and its ally Crimean Khanate. In the new owners it eventually got the name "Khajibey" (although in the documents until the second half of the XVIII century it was also used by Kachibey, Kuchubey, Kujabey, etc.), and later YeniDunya (from Turkic "New World"). And around the fortress - Kochubey Tatarstan, or Khan Ukraine, where settlers and farmers, mainly Ukrainians from the nearest territories, paid "masters" Tatars (represented by their "Hetman of Dubossary" and Khan Ukraine) a tenth of the harvest. The Ukrainian peasants

${ }^{11}$ Levchyshyna O., Pospjelov A. Odesa - moje misto ridne. Navchaljnyj posibnyk dlja uchniv 8-kh klasiv [Odessa is my hometown. Tutorial for 8 grade students]. Retrieved from: http://odessa.gutenbergz.com/menu.html (accessed 11 February 2020)

${ }^{12}$ Levchyshyna O., Pospjelov A. Odesa - moje misto ridne. Navchaljnyj posibnyk dlja uchniv 8-kh klasiv [Odessa is my hometown. Tutorial for 8 grade students]. Retrieved from: http://odessa.gutenbergz.com/menu.html (accessed 11 February 2020) 
to live in Ganshchina - as the people called the Khan's Ukraine - were better than under the lordship... In addition, more and more of them, in particular the citizens of Zaporizhya, began to engage in all sorts of crafts in the Black Sea"13.

On date 1415 accented on her site popular in Odessa travel agency "Tudoy-sudoy" noting: “... the history of Odessa began long before Catherine ... In the 13-14 centuries, when the Northern Black Sea was ruled by Tatars, on the place of today's Odessa was the parking of Genoese ships. Ancient Portolans (nautical charts) brought to us its name - Ginestra (in Italian is called Droch - a bushy plant with yellow flowers, especially common in the Black Sea steppes). As it is known, before the end of the 14th - beginning of the 15th century, the North-Western Black Sea Coast passed from the possession of the Tatars to the Grand Duchy of Lithuania. It was in the $15^{\text {th }}$ century that the first mention in written sources of the settlement of Kachibey, the nearest ancestor of Odessa, was made. When Kachibey appeared, it is not precisely determined and his name was changed many times: Kotsyubeev, Kachibey, Kujabei, Hajibei, Hajibei, Ajibei...". ${ }^{4}$

Interesting is A. Boldarev's argument in favor of the beginning of the chronology of Odessa since 1415, which notes that "Was Odessa founded in 1794? No, it wasn't. This year, there was no city with this name in nature. For the first time, the name "Odessa" in connection with the settlement on the Black Sea coast began to figure in early 1795 . Interestingly, all attempts of prerevolutionary historians to find a legal document that would indicate the renaming of Khajibey to Odessa, were in vain - it was not found"15.

In addition, the historian adds: "In any case with the renaming of Khajibey, the main thing to remember is that in 1794 the settlement with the name of Odessa did not exist. In that case, what was founded on August 22, 1794? It turns out that Khajibey was founded. Wait. It turns out that Khajibey hadn't existed before? Wasn't Khajibey stormed by troops of Russian Empire in 1774 and I789? Wasn't it not in Khajibey where the Russian pledge was placed after a successful assault? To establish Khajibey in Khajibey is as impossible as to establish Ishmael in Ishmael, Moscow in Moscow and Paris in Paris! Let's imagine for a moment that Mordvinov's project would have taken advantage over Deribas's project and the port would have been built hot in Khajibey but in Ochakov, what then - Ochakov would have had to be considered as "founded"

${ }^{13}$ Bachynsjka O. Ghoncharuk T. (2014) ODESA ta ODJeSA - "ne dve boljshye raznycy" [ODESA and ODESA - "not two big differences"] Tyzhdenj ua [Week ua]. (electronic journal) Retrieved from: https://tyzhden.ua/Society/120970 (accessed 11 February 2020)

${ }^{14}$ Ystoryja osnovanye Odessy [History foundation of Odessa] Aghenstvo "Tudoj - Sjudoj" Retrieved from: https://tudoy-sudoy.od.ua/istoriya-osnovanie-odessy/ (accessed 11 February 2020)

15 Boldyrjev O. ODESI-600. Istorychnyj narys. [ODESSA-600. Historical sketch]. Retrieved from: https://storinka-m.kiev.ua/article.php?id=955 (accessed 11 February 2020) 
in 1794 and not at the turn of XIV-XV centuries, as it was in reality and with what everyone agrees?"16

It should be noted that even the "Great Soviet Encyclopedia" avoids direct reference to 1794 as the year of founding the city of Odessa, noting: "Odessa was founded on the site of the pope Kachibey, the first mention of which refers to 1415 . In the 15th century the settlement was destroyed by the Turks, and then it appeared under the name of Khachibey. By Yassky peace treaty of 1791 Khadjibey became part of Russia. In August 1794 in Hajibey by project of engineer F. Devollan under the leadership of A. V. Suvorov and Deribas (see Ribas I.) began to create a naval harbor. In 1795 Khadjibey was renamed to Odessa..."

But the politically engaged history of the founding of the city is presented in the collection "History of towns and villages of the Ukrainian SSR. In particular, the obliquely collected dates of the founding of Odessa clearly stated: "It was at this time, on the place of today's Odessa, a settlement Kachibey (Kotsyubiyiv, Kachikhlenov, Hajibey, etc.) appeared. The first mention of it dates back to 1415 when Kachibey was already a relatively significant port from which grain was exported. There was a large castle on the territory of Kachibey. The remains of the castle were preserved until the middle of the XVIII century ... In the second half of the XVIII century, the Turkish government began construction of Yeni Dunya Fortress near Kacibey. The Ukrainians, the Greeks, the Armenians and others started to settle the city again. At the suggestion of the great Russian commander A. V. Suvorov construction of the fortress in Hadjibey started in 1793. In 1794 works on construction of the new city began. This year is considered the time of the foundation of Odessa. May 27, 1794 there appeared "the highest decree", which stated: "Respecting the favorable position of Khajibey at the Black Sea and the associated benefits, we recognized the need to arrange a military harbour with a merchant's quay. The management of all these works was entrusted and in the future was carried out by Suvorov, one of the main founders of Odessa. The specially created expedition led by IM Deribass and a talented engineer F. Devolan should build a harbor and a city in 5 years. In 1795, Hajibey was renamed into Odessa under the name of the Greek colony Odessa, which once existed near the mentioned territory. The foundation of Odessa was one of the consequences of centuries of the struggle of Ukrainian and Russian peoples for the return of their native Black Sea lands". ${ }^{18}$ However,

\section{${ }^{16}$ Ibid.}

17 Boljshaja sovetskaja encyklopedyja 3-e yzdanye [The Great Soviet Encyclopedia 3 Edition] Retrieved from: http://bse.uaio.ru/BSEOLD/bse3.htm (accessed 11 February 2020)

${ }^{18}$ Istorija mist i sil Ukrajinsjkoji RSR [History of cities and villages of the Ukrainian SSR].

Retrieved from: http://ukrssr.com.ua/odeska/viniknennya-i-rozvitok-mista-odesa (accessed 11 February 2020) 
as we can see even in this source it is stated that the city was within the fortress of Khajibey and until 1794. It should also be noted that the very fact of the existence of a Greek colony with this name remains very questionable.

The analysis of textbooks on the history of Ukraine for general educational institutions showed rather a fragment of mentioning both the creation of Kochubey fortress and the events connected with the assault of Khadjibey fortress by Cossack and Russian troops in 1794. In particular, the textbook "The History of Ukraine" for $7^{\text {th }}$-grade pupils, written by A. Gisem, states: "New victories allowed Vitovt to further expand the borders of his state. Having reached an agreement with the owner of the Golden Horde Tokhtamysh, he began to develop the Black Sea coast between the Dnieper and Dniester. Forts began to be built in Khadjibei (now Odessa), Caravul, Belgorod (Ackerman, now Belgorod-Dnestrovsky), Chornogorod, Dashev (now Ochakov). It also contributes to the formation of the independent Crimean Khanate". ${ }^{19}$

The author of the textbook on the history of Ukraine for the 8th grade $\mathrm{V}$. Vlasov only in a general paragraph concerns the history of the city of Odessa, noting that the last decades of the XVIII century became a time of active colonization of the south of Ukraine and the emergence of new cities. The list of such cities also includes Odessa. Thus, the author of the textbook also begins the chronicle of Odessa in fact from the end of the century. ${ }^{20}$

The authors of the textbook History of Ukraine for the 8th grade G. Shvydko, P. Chernobai still connect the construction of Odessa with Catherine II, which is consistent with the version of the origin of Odessa set out in "History of cities and villages of the Ukrainian SSR. In particular, the authors note: "Mainly based on existing settlements on the southern outskirts of the empire, the government laid down new cities, or renamed the old settlements. Then on the basis of Cossack settlements were laid the provincial city of Yekaterinoslav, port cities Kherson, Nikolaev, Odessa" ${ }^{21}$. Even in the manual for the preparation of EPLL it was noted that 1794 is the date of "the founding of the city on the site of the settlement of Hajibey (from 1795 Odessa) ${ }^{22}$.

${ }^{19}$ Ghisem O. (2015) Istorija Ukrajiny : pidruchnyk dlja 7 kl. zaghaljnoosvit. navch. zakl. [History of Ukraine: a textbook for the 7th form of secondary schools institutions]. Teronpilj: Navchaljna knygha - Boghdan. (in Ukrainian)

${ }^{20}$ Vlasov V. (2016) Istorija Ukrajiny : pidruchnyk dlja 8 kl. zaghaljnoosvit. navch. zakl. [History of Ukraine: a textbook for the 8th form of secondary schools institutions]. Kyjiv: Gheneza. (in Ukrainian)

${ }^{21}$ Shvydjko K., Chornobaj P. (2016) Istorija Ukrajiny : pidruchnyk dlja $8 \mathrm{kl}$. zaghaljnoosvit. navch. zakl. [History of Ukraine: a textbook for the 8th form of secondary schools institutions]. Kyjiv: Gheneza. (in Ukrainian)

${ }^{22}$ Vlasov V., Kuljchycjkyj S. (2014) Istorija Ukrajiny: kompleksne vydannja [History of Ukraine: a comprehensive publication] Kyjiv: Litera. (in Ukrainian) Retrieved from: 
The question arises why, having the publicly available data on the history of Odessa, the majority of Odessa citizens still consider 1794 to be the beginning of chronology of the city. The answer to this question was given very clearly by A. Bachinskaya, noting: "It is difficult to find in Odessa and not only there a man who would not have heard about how much Catherine II did for the city. The Empress is glorified as the founder and benefactor of the city, a person who almost saw in it the future center of the region and through actions paved the way to prosperity. There is also a widely known story that the Empress has changed the male name "Odessos" to the female version of the name of the ancient Greek city "Odessa". And although the first historians are inclined to the fact that it is only a legend and no facts it has not confirmed it yet, this beautiful fairy tale is still known to the citizens of Odessa better than the real events in the history of their cities ${ }^{23}$.

Moreover, for the majority of Ukrainians, things that were included in history textbooks, school curricula, and even more, that do not dissonate the generally accepted opinion, which was formed under the pressure of historical circumstances and does not contradict the historical paradigm that emerged during the Russian Empire turns into a perfect historical fact that does not require proof. Analyzing the textbooks of history of Ukraine for the interpretation of the history of the founding of the city of Odessa showed that even in the conditions of modern Ukrainian educational system the imperial historical tradition of founding the city of Odessa is preserved. Thus, it is worth agreeing that "the transformation of the post-communist system of education can not be successful without constant attention to the process of indoctrination, which involves revealing the ideologizing of education, the dangers of resacralization of the choice and deconstruction of the canon through the demonstration of historical alternatives to religious choice" ${ }^{24}$. And in this case, it concerns not only the date of foundation of the city but also the process of selecting its name in 1795 .

This is confirmed by the preservation of the imperial symbolism in the names of the city streets. And although most of these names were removed during the Soviet period according to the toponymy of Odessa, almost all of

https://erudyt.net/pidgotovka-do-zno/istoriya-ukraini-pidgotovka-do-zno/istoriya-ukrajinykompleksne-vydannya-zno-2014.html (accessed 11 February 2020)

${ }^{23}$ Bachynsjka O. Ghoncharuk T. (2014) ODESA ta ODJeSA - "ne dve boljshye raznycy" [ODESA and ODESA - "not two big differences"] Tyzhdenj ua [Week ua]. (electronic journal) Retrieved from: https://tyzhden.ua/Society/120970 (accessed 11 February 2020)

${ }^{24}$ Kroytor A., Yakovlev D., Aleksentseva-Timchenko K. (2019) 'Apostles' of indoctrination: ideological peculiarities of representation of religious choice in the secondary education (based on analysis of expert interviews) Ideology and Politics, no. 2 (13), pp. 127-146. Retrieved from: https://ideopol.org/wpcontent/uploads/2019/12/ (accessed online 31 December 2019) 
them were returned during the period of independence of Ukraine, in particular, more than 60 street names of the city today have their origin from the times of the Russian Empire and coexist quite organically with the names of the Soviet period and those received after the declaration of independence of Ukraine, in particular during the process of decommunization.

Mythologized Catherine II is a popular folklore character as in Odessa as in Lugansk. The monument to Catherine the Great in Odessa is known to everyone. The Lugansk media from time to time raised the issue of erecting a monument to the Russian Empress as the "highest" founder of the city. Odessa is widely known for the legend that it was the Empress who changed the male name "Odessos" to the female version of "Odessa"25. Among Luhansk residents, there is a legend that the alleged name of a tributary of the Seversky Donets - the river Aidar appeared after the Empress exclaimed: "Ai, dar (a gift)!", - in response to the sturgeon presented to her, caught in the waters of the river. Actually, Ekaterina II never visited the territory of present Lugasnka area, and the name "Aidar" is obviously of Turkic origin.

Odessa and Lugansk are extremely different cities, and the character of Odessa is significantly different from that of Lugansk. But, strangely enough, a closer look at history discovers a kind of "karmic bonds" of the seaport on the Black Sea coast and the military plant on the Lugan River.

Originally, the working settlement, founded by decree of Catherine, was called "Lugansk factory". This name lasted till Alexander III, whose decree from 03.09.1888 "About merge of village Kamenny Brod and settlement Lugansk foundry factory in district city Lugansk" marked the appearance of the city in full sense of the word.

If not going into polemics, to recognize the programming importance of the foundation of the Lugansk plant, it should be noted two important details. 1. A military factory was founded, the main task of which was to produce cannons and cores for the Black Sea Fleet. By the way, on the Borodino field, the Lugansk cannons also boasted. 2. There was founded a public, that is, a state factory. The original workers for this factory were "craftsmen" from other provinces of the empire: Lipetsk, Tula, from the Urals factories.

The factory, designed for the production of weapons, forms a militaristic program of the city community. The state form of ownership stimulates the features of Etatist paternalism. Resettlement of the original inhabitants of the settlement determines the absence of "roots", a significant historical tradition.

Some features of the city's appearance in architectural, psychological and value aspects are comparable with the highlighted features.

${ }^{25}$ Bachynsjka O. Ghoncharuk T. (2014) ODESA ta ODJeSA - "ne dve boljshye raznycy" [ODESA and ODESA - "not two big differences"] Tyzhdenj ua [Week ua]. (electronic journal) Retrieved from: https://tyzhden.ua/Society/120970 (accessed 11 February 2020) 
Some foreign observers point out a strange feature of Lugansk from their point of view: a high "specific weight" of the blocks in comparison with the streets. Sometimes a perplexing question sounds: "Does Lugansk have streets or only blocks"? Apparently, the "block" system is connected with the development of housing stock by enterprises or in connection with the needs of enterprises. Toponyms known to Lugansk citizens are "Southern Quarters", "Eastern Quarters" (in the vernacular of "Quarter" - specific Lugansk jargon), "OR Plant Town", "OR Plant Settlement", etc.

It should be noted that under the Soviet regime, 44 out of 70 Lugansk factories were directly or indirectly connected with the military-industrial complex.

To understand the mentality of Lugansk people it makes sense to pay attention to the following seemingly inconspicuous, but significant detail. Lugansk is mentioned several times in the Ukrainian history textbooks for the 9 th grade of general education institutions in the general context. For example, in the textbook "History of Ukraine for 9th grade," A. Strukevich, in the context of the Crimean War-related events, notes that "it was to a large extent the Ukrainian military industry that provided the army with military supplies. Lugansk factory increased the production of shells almost fourfold, Shostkins gunpowder factory produced six times more gunpowder - almost as much as the other factories in Russia" 26.

The next mention of Lugansk in this textbook is the thesis that "At the end of the century the first transport engineering enterprises - Kharkiv and Lugansk steam locomotive plants - appeared in Ukraine. By 1900, they had produced 233 steam locomotives" 27 .

Lugansk is mentioned a little bit more in the Ukrainian history textbook for $10^{\text {th }}$-grade pupils. The city is mentioned in the context of the struggle of the UNR troops with the Bolsheviks. In particular, the authors of the textbook A. Hysem and A. Martyniuk note: "Having suffered a defeat in Kiev, the Bolsheviks were not going to give up power in Ukraine. During November, they managed to seize power in Lugansk". The next mention in the textbook Luganskaia is a report on the implementation of the GOELRO plan in 1920 in Ukraine and the commissioning of the power plant in Lugansk. In this textbook, in the context of the story about the beginning of the liberation of Ukraine from Nazi forces, it is stated: "The first settlement liberated on December 18, 1942, was 218 division VI village Pivnevka Voroshilovgrad (now Lugansk) region. Further in the text, once again mentioned Lugansk, namely: "On March 15,

${ }^{26}$ Strukevych O. (2017) Istorija Ukrajiny : pidruchnyk dlja 9 kl. zaghaljnoosvit. navch. zakl. [History of Ukraine: a textbook for the 9th form of secondary schools institutions]. Kyjiv: Ghramota. (in Ukrainian)

${ }^{27}$ Ibid. 
1943 German troops captured Kharkiv again, and on March 18 - Belgorod. Under the control of the Soviet troops remained only the north of Voroshilovgrad and the eastern part of Kharkov region" ${ }^{28}$. This textbook also contains a photograph showing the removal of the bells from the temple in Lugansk in 1929.

Much more about Lugansk is mentioned in the Ukrainian history textbook for 11th-grade pupils. In particular, the authors of the textbook V. Vlasov and S. Kulchitsky posted a photo with the image of the diesel locomotive and a comment: "The diesel locomotive of the TEZ No. 2068 series, built at the Voroshilovgrad (Lugansk) Diesel Locomotive Plant. Diesel locomotive FEZ became the most massive series in the network of Soviet railways ${ }^{29}$.

This textbook contains a fragment of an interview with Nikolai Rudenko on the establishment of the Ukrainian Helsinki Group and a meeting of some of its representatives in the Lugansk region. Luhansk region is also mentioned quite fragmentarily in the textbook during the presentation of the material dedicated to the "orange revolution," in particular: "During the meeting, representatives of the opposition said that in Donetsk region Yanukovych "drew" 1 million 200 thousand votes for himself, in Luhansk - up to 500 thousand, in Mykolaiv, Kherson, Odessa, Zaporizhzhya and Dnipropetrovsk combined -1 million ... Immediately after the announcement of the falsified results of the second round of the CEC, Yushchenko appealed to the Supreme Court of Ukraine through an authorized representative, demanding that the results of the vote in Donetsk and Luhansk regions be declared invalid due to massive violations of law and distortion of the results of the public will expression" ${ }^{30}$.

Lugansk region is also mentioned in the paragraph devoted to the armed aggression of Russia against Ukraine in this context: "It began with the seizure of administrative buildings in Lugansk and Donetsk regions, which allowed terrorists to take power in many cities of the region. In this paragraph there is a chronological line with the date and the inscription: "April 2014. Occupation by terrorists in Donetsk and Lugansk. In addition, the authors note, "In Lugansk, on April 6, they captured the regional branch of the SBU ... However, the situation in Donetsk and Luhansk oblasts was getting hotter. On 12 April, a group of SBU officers and Alpha units were ambushed near Slavyansk. The

${ }^{28}$ Ghisem O. Martynjuk O. (2018) Istorija Ukrajiny : pidruchnyk dlja 10 kl. zaghaljnoosvit. navch. zakl. [History of Ukraine: a textbook for the 10th form of secondary schools institutions]. Kharkiv: Ranok. (in Ukrainian)

${ }_{29}$ Vlasov V. Kuljchycjkyj S. (2019) Istorija Ukrajiny : pidruchnyk dlja 11 kl. zaghaljnoosvit. navch. zakl. [History of Ukraine: a textbook for the 11th form of secondary schools institutions]. Kyjiv: Litera. (in Ukrainian)

${ }^{30}$ Ibid. 
authors also mention Lugansk and Lugansk region from the following angle: "By the end of April 2014 on the territory of many settlements of Donetsk and Lugansk regions the militants captured dozens of state infrastructure objects and carried out armed attacks on units and parts of the Ukrainian law enforcement agencies. April 27th was announced to "Lugansk National Republic" 31 .

Another mention of Lugansk region in the textbook happens when describing the events related to the signing of the Minsk agreements, in particular, the authors point out: "The protocol mentioned the obligations of Ukraine to ensure by law the "special status" of certain districts of Donetsk and Luhansk regions. However, this notion was blurred. The monitoring of the ceasefire regime by the OSCE was not concretised either... As a result of long negotiations, the leaders of the Quartet agreed on an immediate and comprehensive ceasefire in some areas of Donetsk and Lugansk regions ... On the territory uncontrolled by Ukraine in Lugansk and Donetsk regions of the Russian Federation pulled down a large number of weapons, in particular 558 tanks" ${ }^{\prime 2}$.

In general, the Ukrainian history textbook for grade 9 mentions Lugansk and Lugansk region twice, and the textbook for grade 10 mentions four times. But the textbook for the 11th grade mentions Lugansk and Lugansk region fifteen times. In this context, it should be noted that "constructing the political reality of the future is impossible without a historical interpretation and categorization of the past" ${ }^{\prime 3}$. After all, the historical memory of certain social groups and society as a whole affect the spatial orientation of the population and its self-identity, which is expressed in particular in the mentality of not only Lugansk or Odessa residents, but also the population of other regions of the country.

\section{2. "Lugansk mentality" today: formation and features}

Lugansk flourished in the $60 \mathrm{~s}-70 \mathrm{~s}$ of the twentieth century. True, it was "Soviet socialist" prosperity, far from the standards of the prosperity of developed capitalist countries, but a Soviet citizen who was not familiar with these standards was quite satisfied with it. Lugansk prosperity had both a material aspect and a "quasi-spiritual" one. The material aspect was expressed

31 Vlasov V. Kuljchycjkyj S. (2019) Istorija Ukrajiny : pidruchnyk dlja $11 \mathrm{kl}$. zaghaljnoosvit. navch. zakl. [History of Ukraine: a textbook for the 11th form of secondary schools institutions]. Kyjiv: Litera. (in Ukrainian)

${ }^{32}$ Ibid.

${ }^{33}$ Jakovlev, D., \& Krojtor, A. (2018). Istorija vyboru ta vybir istoriji. Relighijnyj vybir Kyjeva u pidruchnykakh Ukrajiny. [Choice History and History Choice. Kyiv's religious choice in Ukrainian textbooks] Reghionaljna polityka: istorija, polityko-pravovi zasady, arkhitektura, urbanistyka: zb. nauk. pracj. Kyjiv - Ternopilj: Beskydy, pp. 38-44. 
in the comparative abundance of Lugansk shop counters (compared, for example, with the Rostov region). The football sensation of 1972 - gold medals of Lugansk "Zarya" in the USSR championship - can be considered a conditionally spiritual success. By the way, "Zarya" was the first team not from the capital city, which won the championship of the Union.

Looking back at the recent past from the "height" of the current years, we cease to be surprised by strong nostalgia for the Soviet stagnation, enveloping the souls of most Lugansk people. By the way, this nostalgia was an important psychologically-axiological factor that contributed to "hot support" of separatist moods. If you "scrape" the Donbas separatist, you will find in his soul nostalgia for stagnation.

In the article of 1997, the following characteristics of the mentality of a typical Lugansk resident were highlighted:

1. Paternalism.

2. Militarism.

3. The combination of paternalism and militarism gave rise to authoritarianism. Discipline and order were a priority in Lugansk's value system. Moreover, the Lugansk resident preferred not self-discipline, but discipline brought from outside by the "firm hand". One of the manifestations of the authoritarian discipline of Lugansk people is a high overcoming power, typical for a typical representative of the Lugansk community. And it is not so much the active force of overcoming someone else's will, unfavorable circumstances, obstacles, etc., as the passive power of undergoing, the irresistible force of obedience, the ability to demolish everything, to endure everything, to survive in spite of everything. The Lugansk man is not so much brave as hardy. The average Lugansk resident will ignore the difficulties that will seem unbearable to a Kievan or Odessa citizen.

4. Internationalism. For a Lugansk resident, class affiliation is much more important than national affiliation. The average Lugansk resident, as well as the entire Donbasian, is a "natural Marxist". Lugansk scientist A. N. Litvinov expressed an idea worthy of attention: despite the ridicule of intellectuals, "a new community of people - the Soviet people" was still formed, however, in a separate region. And this region is Donbass. However, the events of the Donbas conflict make adjustments in particular to the Donbas mentality. Until 2014, the issue of national identity was not very worrying the hearts of Lugansk citizens. It seems that from now on it will find a "hot response" in the "Donbass soul".

5. Conservatism, cautious perception of the new.

6. The prevalence of industrial and economic mentality over humanitarian mentality. In the eyes of a typical Lugansk resident "real" work is physical labor in heavy industry. 
7. Ingenuity, absence of a significant tradition. With the presence of a rather pronounced regional patriotism with elements of "Donbas pride" contrasts with the motive of "faraway lands" present in the mentality of the Donbas people. Deep down, the Lugansk resident understands that there are, to put it mildly, not very comfortable conditions, but his efforts are usually aimed not at improving these conditions, but at finding the best ones wherever they are. Luganchanin, so to speak, is "easy to move up": it is easier for him to move than to "cultivate his garden".

The following objection is raised with regard to the features of the Lugansk character we have identified: to what extent are these features relevant to the Lugansk people? Many of these features, to a greater or lesser extent, were inherent in the mass citizen of the Soviet Union, that is, the very "scoop" that came off the pages of brilliant journalism A. Zinoviev. Didn't we describe the "scoop" instead of the typical Lugansk resident of the typical homo soveticus, the enfant terrible of post-perestroika liberal consciousness?

The rebuke is undoubtedly fair. Let's put forward the following counterargument as an excuse. Indeed, a Donbasian, a Lugansk resident in particular, is a typical representative of a Soviet man. But, first of all, it follows from this that the features of the psychological image of a Soviet man are characteristic features of a Lugansk resident. Second, some social groups turn out to be the most representative for understanding the essential features of the larger social community of which they are a part. It is in these social groups that the essential features of the social community of which they are a part are most vividly displayed. And we assume that the people of Donbas, particularly the people of Lugansk, are not just representatives, but, so to speak, classical representatives of homo soveticus.

The events of 2014-2019 undoubtedly require adjustments to the Lugansk concept. But these adjustments consist not only in clarifying and amending the stated provisions. Obviously, a number of provisions of the 1997 article are correct; some provisions have explanatory and predictive force regarding the event level of the Donbas conflict, as well as the peculiarities of the Donbas mentality.

First of all, in the context of such peculiarities of Lugansk character as paternalism, militarism and authoritarianism, the stable sympathies of Lugansk residents towards Putin's Russia and personally towards V. Putin are quite understandable. In the minds of many Lugansk residents, current Russia is a natural continuation of the lost Soviet Union. Its power (perhaps, it seems), its military might, the revival of militarism, both in ideology and in practice, - all these features of Putin's Russia are very attractive to a typical Lugansk resident. $\mathrm{He}$ perceives peacefulness as a weakness; he is impressed by healthy aggression. 
The conservatism of the Lugansk people that we have noted partially explains the effectiveness of one of Putin's propaganda features, namely the emphasis on the value of a stable order and the intimidation of change. In general, intimidation is a very effective manipulative strategy with regard to conservative consciousness. At the same time, it becomes indifferent to what is presented as threatening factors: Bandera, Maidan, gay and lesbian Europeans, American imperialism, or some mythical "fascists" who grow up to be a symbol of universal evil. First of all, it is indifferent whether these pseudosubstantiations constructed by propaganda efforts pose a real threat; secondly, it is indifferent whether they are connected. The main thing is to connect them with the pernicious and sinful "novelty" that is looming on the unfortunate "Donbas people" from the foggy faraway unknown West.

Next: Paternalism undoubtedly forms a passive social character. It is worth noting the impressive passivity of the Luhansk people during the events of spring-summer 2014. Euromaydan in Lugansk, as a rule, did not gather more than two hundred or three hundred people; in rare cases, it gathered more than five hundred participants. This is in the case of half a million inhabitants of the city. Of course, this passivity is partly due to the obvious or hidden sympathies of the majority of city dwellers for Putin's Russia and, consequently, for the "Novorossiya" project and other separatist ideologies. (It must be said that for many Luhansk residents, separatism as such was of no value - the region's fake independence was thought to be the initial stage in the process of entering Russia).

Still, a considerable number of patriotic citizens lived in Lugansk. So why didn't they provide an impressive mass of Euromaydan? Their prevailing mood expressed well the thought that was often heard from their lips in conversations with the authors: "This is none of our business. We believed that the authorities should put things in order".

However, the passivity of the Luhansk people should not be exaggerated. Emigrant observations of the psychological image of the inhabitants of other cities of Ukraine, supported by the observations of the Donbas migrants, who found shelter in these cities, convince us that civil passivity is a problem for a significant part of our population. According to many Lugansk resettlers, if the goal was to provoke separatist sentiments in many cities of eastern Ukraine, it would be no less successful than in Donbas. On the other hand, the facts of the separatists' defeat in Kharkiv, Dnipropetrovsk and Odesa contradict this opinion. The question remains open.

It should be noted that in the shadow of the masters a rather strong intellectual layer of Lugansk humanitarian intelligentsia was formed. It is interesting that one of the characteristic features of the mentality of this layer is a rather pronounced metaphysical character. The reflection on the events of 
2014-2015 in Donetsk was reflected in the work of Donetsk intellectuals called "Metaphysics of Donetsk" "34. Unfortunately, Lugansk emigration cannot boast of such work. But we have a slightly different meaning in mind: we are not talking so much about the metaphysics of Lugansk, but about the metaphysics of the Lugansk people. Metaphysical connotations are inherent in Lugansk's philosophical discourse, both professional and, to an even greater extent, amateur. A Lugansk man, so to speak, is "by nature a metaphysicist". (It should be explained that in the whole previous context we used the word "metaphysics" in the Aristotelian sense - as "first philosophy"). The dominant historical and philosophical discourse in contemporary philosophical thinking is not at all the same in Lugansk. The Lugansk lover of philosophy will certainly be impressed by the speaker's historical-philosophical erudition at a discussion club or symposium. But it will not impress him to the core. The Lugansk man will say something like that: "It's all good, of course, but what's your own teaching?" The Luganian humanitarian prefers his philosophy to historicalphilosophical professionalism, even if it turns out to be dilettantish.

By the way, in this particular case we can see a remote and controversial, but, in our opinion, a kind of mental foundation for sympathy for imperialism, Eurasianism and all kinds of "duginism": the Lugansk intellectual is convinced that political practice should be rooted in some kind of metaphysical foundation.

\section{CONCLUSIONS}

The issue of the Donbas identity remains controversial. Not only in journalism, but also in scientific research, there was an opinion about the Donbas people as a special socio-cultural and even ethnic community. Naturally, in the consciousness of the Donbas residents, there was a more or less pronounced sense of regional identity, however, as in the consciousness of the residents of any region. In connection with the events of the Donbas conflict, this feeling became stronger. It would be premature to believe that this feeling marks the emergence of a new national community. But, as they say, "the process has gone". If the current state of affairs in Donbas is put on hold, the sense of regional identity will increase and in the future may lead to the formation of some kind of Donbas quasi-nationality. It should be explained that the mentioned process will involve, first of all, the residents of the occupied territories.

I would like to draw attention to some peculiarities of the mentality, in our opinion, of the neglected strata of the Donbas population - the settlers. This

${ }^{34}$ Ghurzhy V., Bilokobyljsjkyj O., Dodonov R., ta in. (2012) "Metafyzyka Donecka" [Metaphysics of Donetsk] Retrieved from: https://donbasstudies.org/book/metafizika-donetska/ (accessed 11 February 2020) 
group is, undoubtedly, quite diffuse. Social status, economic well-being, world outlook and political values of representatives of this group are quite different. Nevertheless, in our opinion, it is possible to speak about the Donbas migrants as an integral community. One of the spiritual and psychological factors in the constitution of the integrity of this group can be considered a peculiar feature of the mentality of immigrants - the obvious or implicit sacralization of Donetsk and Lugansk in the nostalgic consciousness of emigrants. Such processes to a certain extent characterize the consciousness of any emigrant group.

Earlier, one of the authors put the Luhansk citizens metaphor of "new postmodern Jews" into circulation. In the consciousness of some part of the Lugansk emigrants, the abandoned city acquires the features of a kind of sacral symbol, the lost "promised land," the "wall of crying," to which one must return. It is possible to assume that similar moods take place among the immigrants from Donetsk. Will the Donbasians preserve their spiritual community or will they dissolve into the crucible of the modern geopolitical brew without a trace? If they do, the modern world will acquire a kind of "invisible" community with high creative potential.

If it was necessary to characterize the essence of what is happening in Donbass in one word, we would certainly choose the word "tragedy". The events of the Donbas conflict resemble the ancient Greek tragedy almost in the purity of the genre. Let's remind the classical definition of the best tragic fable that Aristotle gives: in a well-compiled story (fable) it is necessary that the change in it takes place not from misfortune to happiness, but on the contrary, from happiness to misfortune and not because of viciousness, but because of a great mistake of a man such as it is said [not distinguished by "neither virtue nor righteousness"], and if it is not, it is rather better than worse.

The Donbas drama reproduces this fable with amazing accuracy. Like most of the representatives of homo sapiens, the Luhansk citizens were rather the best than the worst people, and they were not distinguished by either special virtue or righteousness. And they voluntarily, on their own naivety, and partly driven by lowly passions, committed acts that led them from happiness to misfortune, and some to death. In anticipation of the boundless and seemingly inevitable happiness, they opened their brains to a deadly bullet.

Honorable spectators! Cry, weep, sympathize, and most importantly become better, watching the Tragedy of Donbass.

\section{SUMMARY}

The specificity of Lugansk mentality in the context of Donbas political consciousness (mentality) is considered in the article. The influence of "archipelago events" on the historical development of social communities and the peculiarities of historical memory regarding the founding of the cities of 
Odesa and Lugansk in the context of historical discourse that dominates the worldviews of the residents of these cities. There fore archiptypical events are able to program the value system of individual communities, forming a relevant supremacy of its life activity. It is proved that the peculiarity of the Lugansk mentality is the tendency to authoritarianism, paternalism, internationalism, conservatism and the absence of a significant cultural and historical tradition. It is anslized the influence of these traits as a metal-psychological basis of modern conflict in the Donbass.

\section{REFERENCES}

1. Bachynsjka O. Ghoncharuk T. (2014) ODESA ta ODJeSA - "ne dve boljshye raznycy" [ODESA and ODESA - "not two big differences"] Tyzhdenj ua [Week ua]. (electronic journal) Retrieved from: https://tyzhden.ua/ Society/120970 (accessed 11 February 2020)

2. Boldyrjev O. ODESI-600. Istorychnyj narys. [ODESSA-600. Historical sketch]. Retrieved from: https://storinka-m.kiev.ua/article.php? id=955 (accessed 11 February 2020)

3. Boljshaja sovetskaja эncyklopedyja 3-e yzdanye [The Great Soviet Encyclopedia 3 Edition] Retrieved from: http://bse.uaio.ru/BSEOLD/bse3.htm (accessed 11 February 2020)

4. Denj ghoroda. Proghramma [City day. Program] Oficijnyj sajt mista Odesa Retrieved from: https://omr.gov.ua/ua/announce/216868/ (accessed 11 February 2020)

5. Eremenko A., Yakovlev D. (2019). "My dialektiku uchili ne po Gegelyu". Filosofiya v zerkale politicheskoy propagandy: popytka antropologicheskogo podkhoda ["We studied dialectics not according to Hegel". The philosophy in the mirror of political propaganda: an attempt to the anthropological approach] Current problems of philosophy and sociology, no. 24, pp. 10-23. https://doi.org/10.32837/apfs.v0i24.885 (accessed 11 February 2020)

6. Erëmenko A. M. (2005) Ystoryja kak sobutyjnostj: Monoghrafyja: V 2-kh t. T. 2. [History as an Event: Monograph: In 2 volumes. Volume 2] Lughansk: RYO LAVD, (in Ukrainian)

7. Erëmenko A. M., Sneghyrëv V. V. (1997) Lughansk: myfologhyzyrovannoe proshloe y vozmozhnoe budushhee [Lugansk: mythologized past and possible future] Drevnosty Podoncovjja, pp. 81-84.

8. Ghisem O. (2015) Istorija Ukrajiny : pidruchnyk dlja $7 \mathrm{kl}$. zaghaljnoosvit. navch. zakl. [History of Ukraine: a textbook for the 7th form of secondary schools institutions]. Teronpilj: Navchaljna knygha - Boghdan. (in Ukrainian) 
9. Ghisem O. Martynjuk O. (2018) Istorija Ukrajiny : pidruchnyk dlja $10 \mathrm{kl}$. zaghaljnoosvit. navch. zakl. [History of Ukraine: a textbook for the 10th form of secondary schools institutions]. Kharkiv: Ranok. (in Ukrainian)

10. Ghurzhy V., Bilokobyljsjkyj O., Dodonov R., ta in. (2012) "Metafyzyka Donecka" [Metaphysics of Donetsk] Retrieved from: https://donbasstudies.org/book/metafizika-donetska/ (accessed 11 February 2020)

11. Istorija mist i sil Ukrajinsjkoji RSR [History of cities and villages of the Ukrainian SSR]. Retrieved from: http://ukrssr.com.ua/odeska/viniknennya-irozvitok-mista-odesa (accessed 11 February 2020)

12. Jakovlev, D., \& Krojtor, A. (2018). Istorija vyboru ta vybir istoriji. Relighijnyj vybir Kyjeva u pidruchnykakh Ukrajiny. [Choice History and History Choice. Kyiv's religious choice in Ukrainian textbooks] Reghionaljna polityka: istorija, polityko-pravovi zasady, arkhitektura, urbanistyka: zb. nauk. pracj. Kyjiv - Ternopilj: Beskydy, pp. 38-44.

13. Kroytor A., Yakovlev D., Aleksentseva-Timchenko K. (2019) 'Apostles' of indoctrination: ideological peculiarities of representation of religious choice in the secondary education (based on analysis of expert interviews) Ideology and Politics, no. 2 (13), pp. 127 - 146. Retrieved from: https://ideopol.org/wpcontent/uploads/2019/12/ (accessed online 31 December 2019)

14. Levchyshyna O., Pospjelov A. Odesa - moje misto ridne. Navchaljnyj posibnyk dlja uchniv 8-kh klasiv [Odessa is my hometown. Tutorial for 8 grade students]. Retrieved from: http://odessa.gutenbergz.com/ menu.html (accessed 11 February 2020)

15. P. Ricoeur (2004) Pamjatj, ystoryja, zabvenye [Memory, history, forgetting]. Moskva: Yzdateljstvo ghumanytarnoj lyteratury. (in Russian)

16. Shtompka P. (2001) Kuljturnaja travma v postkommunystycheskom obshhestve [Cultural trauma in a post-communist society] Socyologhycheskye yssledovanyja, no. 2, pp. $23-38$.

17. Shtompka P. (2001) Socyaljnoe yzmenenye kak travma (statjja pervaja) [Social change as trauma (article one) SOCYS., no. 1, pp. 6-16.

18. Shvydjko K., Chornobaj P. (2016) Istorija Ukrajiny : pidruchnyk dlja $8 \mathrm{kl}$. zaghaljnoosvit. navch. zakl. [History of Ukraine: a textbook for the 8th form of secondary schools institutions]. Kyjiv: Gheneza. (in Ukrainian)

19. Strukevych O. (2017) Istorija Ukrajiny : pidruchnyk dlja $9 \mathrm{kl}$. zaghaljnoosvit. navch. zakl. [History of Ukraine: a textbook for the 9th form of secondary schools institutions]. Kyjiv: Ghramota. (in Ukrainian)

20. Vlasov V. (2016) Istorija Ukrajiny : pidruchnyk dlja $8 \mathrm{kl}$. zaghaljnoosvit. navch. zakl. [History of Ukraine: a textbook for the 8th form of secondary schools institutions]. Kyjiv: Gheneza. (in Ukrainian) 
21. Vlasov V. Kuljchycjkyj S. (2019) Istorija Ukrajiny : pidruchnyk dlja $11 \mathrm{kl}$. zaghaljnoosvit. navch. zakl. [History of Ukraine: a textbook for the 11th form of secondary schools institutions]. Kyjiv: Litera. (in Ukrainian)

22. Vlasov V., Kuljchycjkyj S. (2014) Istorija Ukrajiny: kompleksne vydannja [History of Ukraine: a comprehensive publication] Kyjiv: Litera. (in Ukrainian) Retrieved from: https://erudyt.net/pidgotovka-do-zno/istoriyaukraini-pidgotovka-do-zno/istoriya-ukrajiny-kompleksne-vydannya-zno2014.html (accessed 11 February 2020)

23. Ystoryja osnovanye Odessy [History foundation of Odessa] Aghenstvo "Tudoj - Sjudoj" Retrieved from: https://tudoy-sudoy.od.ua/istoriyaosnovanie-odessy/ (accessed 11 February 2020)

24.Zakharchenko R. S. (2007) Kam'janyj brid [The stone ford] Encyklopedija istoriji Ukrajiny: u 10 tomakh Tom 4 [Encyclopedia of Ukrainian History: in 10 volumes. Volume 4.

\section{Information about the authors:} Yeremenko O. M., Prof. dr hab., Head of the Department of Philosophy, National University Odessa Law Academy 23, Fontanska str., Odessa, 65009, Ukraine ORCID ID: orcid.org/0000-0002-2922-0643

Kroytor A. V., $\mathrm{PhD}$, Department of Political Science, National University Odessa Law Academy 23, Fontanska str., Odessa, 65009, Ukraine ORCID ID: orcid.org/0000-0003-4652-7441 